\title{
Spatial Distribution of Tribal Population and Inter Tribal Differences in Population Growth: A Critical Review on Demography and Immigration in Assam
}

\author{
${ }^{1}$ Sailajananda Saikia, ${ }^{2}$ Bishmita Medhi, ${ }^{3}$ Bidyum Kr Medhi \\ ${ }^{l}$ Centre for Studies in Geography, Dibrugarh University: \\ ${ }^{2}$ Research Scholar, NEHU.Shillong, ${ }^{3}$ M Phil. Student J.N.U Delhi
}

\begin{abstract}
Assam holds and supports a large proportion of tribal population, highly differentiated in terms of ethno-lingual characteristics as well as economic responses to their habitats. Ethnic violence, which has become endemic to the states of postcolonial Northeast India especially Assam, has often targeted people of migrant origin as foreigners or illegal immigrants to sent them back to their lands of origin. The Muslim and Hindu Bangladeshi migrant who have been migrating to Northeast India since the colonial times have mingled with the multi-ethnic and multi-cultural society of the region. Settled in almost all the states of the region they have, in recent times, been frequently identified as foreigners as their growing numbers have become a threat to the ethnicity. Immigrants from both Nepal and Bangladesh have created a cause of concern for the indigenous ethnic tribal population in different sphere. An attempt is made in this paper to examine different growth pattern among the tribal living in the state and also the migrated population which is growing in an alarming rate. This paper looks at the conflict-induced displacement of the Bangladeshi in Assam. Moreover, government also has not taken step to reduce the inflow, which has induced demographic problem in the region and raised question on government concern for the ethnic groups. The paper also looks at the long term effect of migration on culture, social and economic demographic and political instability in the region.
\end{abstract}

Keywords: Indigenous Ethnic tribes, Demography, Economy, Immigration.

\section{Introduction:}

A very significant proportion of India's population has been recognized as Schedule Tribes (ST). This section which accounts for around 8 percent of India's total population is not homogeneous either socially or economically. They belong to different ethno-lingual groups, profess diverse faith and are at disparate level of socio-economic development.The tribal communities exhibit a highly uneven distribution.

There are two main areas of tribal concentration: (a) Central Indian uplands around the Vindhyan subregion, and (b) north-eastern parts of the country. In general, tribal population is mainly concentrated in the hilly and forested tracts of the country. More than 87 per cent of the country's tribal population is confined to 11 states (Madhya Pradesh 14.51 percent, Maharashtra 10.17, Orissa 9.66, Gujarat 8.87, Rajasthan 8.42, Jharkhand 8.40, Chhattisgarh 7.85, Andhra Pradesh 5.96, West Bengal 5.23, and Assam 3.92 per cent) of the country.

An interesting aspect of the tribal population and their geographical distribution is the tendency of this segment to cluster and concentrate in a few pockets in diverse degrees of isolation within an environmental setting which is by and large averse to intensive settled cultivation. Because of this face it is observed that the tribal population of this region from the very past lack to adequate interaction of between the tribal and non-tribal components of population.

One of the most interesting facts of tribal study in India is that it is neglected most of the time but no study on tribal geography and demography is complete without a reference to the north-east India in more than one sense the north eastern region represent a microcosm of the entire subcontinent. The typical distribution pattern demands studies to be conducted for different tribes separately as the habitat, resource base; cultural patterns vary over space as one moves from one tribal group to enter another.

An important dimension of the tribal situation in the north east in general and Assam in particular refers to the dynamics of demographic changes taking place among these communities of varying size and located in diverse ecological milieu. An attempt is made in this paper to examine and analysis inter-tribal difference in the population growth and impact of migration population to Assam from Bangladesh which poses a threat to the demographic balance in the state.

\section{The Region -Assam:}

Assam is one of the seven states of Northeast India. It is situated within $24^{\circ}$ and $28^{\circ}$ North latitudes and $49.8^{\circ}$ and $96{ }^{\circ}$ East longitudes. Assam is bounded by Bhutan and Arunachal Pradesh on the north, Meghalaya and Tripura on the south, Manipur, Nagaland and Arunachal Pradesh on the east and Meghalaya and West Bengal and Bangladesh on the west. Assam covers a territory of 78,523 sq km, roughly a 
fourth of it comprising rugged hills and the rest verdant alluvial plains out of which $78,088 \mathrm{sq} \mathrm{km}$ is occupied by rural and $485 \mathrm{sq} \mathrm{km}$ is occupied by urban areas. The alluvial Brahmaputra valley commands the lion's share of the territory. According to 1991 census, the total population of the state is $22,414,322$ out of which 11.09 percent are urban and 88.89 per cent are rural inhabitants. The state of Assam is divided into 28 districts. Of the total districts, two districts are hills districts. These are Karbi Anglong and North Cachar Hills districts. Assam is blended with hills and plains. Topographically it can be divided into three distinct zones: the Brahmaputra valley or the Brahmaputra plains in the north; the Karbi Anglong and the North Cachar Hills in the middle; and the Barak valley or the Barak plain in the south. The Brahmaputra valley which is about $500 \mathrm{~km}$ in length and $60 \mathrm{~km}$ in breadth is the most expansive plain area of the three zones. The Brahmaputra itself is highly braided due to low gradient and tends to form river islands. The largest of them, Majuli (929 sq kms) is said to be the world's largest. In the valleys of the Brahmaputra and the Barak, the soils are mostly alluvial. In the hill areas the soils are red in colour and they are also acidic. The climatic condition of the plains is quite suitable for the cultivation of the variety of crops and the climatic condition of the soils in the hill areas are quite suitable for cultivation of certain crops like coffee and rubber. Assam has an agricultural based economy and more than 70 per cent of the population depends on agriculture as their primary source of livelihood. Rice is the main crop cultivated by the people. In the interior hill areas, the tribal people practice shifting cultivation. The tribal people raise mixed crops along with paddy in jhum cultivation. Racially, there are a number of ethnic groups in Assam including the indigenous tribal communities professing different religious faiths and beliefs and speaking different languages and dialects.

The state has a large number of tribes with their variety in tradition, culture, dresses, and exotic way of life. Most tribes have their own languages; some of their traditions are so unique and lively that these causes wonder to others. Boro (or Kachari), Karbi, Koch-Rajbanshi, Mishing, Mishimi and Rabha are also among these tribes exhibiting variety in tradition, culture, dresses, and exotic way of life. Assamese is the principal language of the state and is regarded as the lingua franca of the whole North East India.

In Assam there are as many as 23 tribal communities which constitute 12.82 per cent of the total population of the state. The tribes of Assam may broadly be divided into two categories: plain tribes and hill tribes. The plain tribes mainly inhabit the plain areas of the state and the hill tribes are mainly concentrated in the hilly areas. Bodo Kacharis constitute the largest tribal group in Assam who account for 38 per cent of the total tribal population of the state. Next to the Bodo Kacharis, the Mishings constitute 16.16 percent of the total tribal population .The district wise breakup of tribal population in Assam shows that in North Cachar Hills district the tribals constitute 65.54 per cent of the total population of the district. In Karbi Anglong district, the tribals constitute 51.56 per cent of the total population of the district. In Dhemaji district, they constitute 43.92 per cent and in Kokrajhar district they constitute 41.15 per cent. A significant percentage of tribal population in the districts of Kamrup, North Cachar Hills, Karimganj, Dibrugarh and Hailakandi are urban. Their percentages are 11.83 (Kamup), 11.76 (Nath Cachar Hills district), 8.68 (Karimganj), 7.93(Dibrugarh) and 6.72 (Hailakandi).

Assam, according to the 2011 Census report, has registered a decadal population growth of 16.93 per cent during the last decade compared to 18.92 per cent growth recorded in the 2001 report. The report also revealed that the sex ratio in the State (number of females per 1,000 males) has increased from 935 to 954 . The population growth rate of the State is less than the national growth rate, which stands at 17.64 per cent.

While the total population of Assam stood at 2,66,55,528 in 2001, the latest report puts the total enumerated population at 3,11,69,272 persons taking the decadal growth of population up by $45,13,744$ persons. The Census report was handed over to media persons today by RK Das, Director, Census Opearations, and Assam at a press conference. While the male population rose to $1,59,54,927$ scoring a growth of 15.81 per cent, the female population stood at $1,52,14,345$ with a growth of 18.14 per cent.

The highest growth rate at the district level has been recorded by Dhubri (24.40 per cent) which borders Bangladesh closely followed by Morigaon ( 23.39 per cent) and Goalpara (22.74 per cent). The lowest growth rate has been witnessed in Kokrajhar. Of the 27 districts, eight districts registered rise in the decadal population growth rate.The report also stated that the population in the age-group of 0-6 years has ascended to $4,511,307$, further classifying the total (0-6 years) in persons between male and female as 2305088 and 2206219 respectively."While the growth rate of enumerated males in the age-group of 0-6 years stood at 14.47 per cent from 16.87 in 2001, the female growth rate went down from 16.62 per cent in 2001 to 14.50 per cent," the 2011 census report pointed out.

All the districts barring Darrang have shown significant improvement in the sex ratio, the highest been recorded in Morigaon (974), while the lowest ratio has been observed in the district of Kamrup (Metro) with 922. Further, according to the provisional population calculated at the Census of India 2011, the density of population per square kilometer has gone up to 397 as against 340 in 2001 with no change in the State area of 78,438 square kilometre. 
Spatial Distribution Of Tribal Population And Inter Tribal Differences In Population Growth: A

The report divulged that Kamrup (Metro) has the highest density of population $(2,010)$ followed by Dhubri $(1,171)$ and Baksa $(763)$, while the lowest density has been seen in Karbi Anglong, with no change from the 2001 census report.

\section{Spatial Distributions of Tribal Population:}

The Tribes are generally classifies on the basis of territory, language, occupation, physical characteristics and cultural contact. Like the rest of India while considering the tribal population there is some difference with their nature. The tribes of Assam are not primitive, nor they are very backward and all of them are not hill-dwellers or forest dwellers. They are hardly cut-off physically and socio-culturally from non-tribes.

While considering the tribal population and there spatial distribution in Assam, they could be broadly classified under two groups: - 1). Hill tribes and 2). Plain tribes. Among the Hill Tribes the Karbi and the Dimasa's are the most important groups. The Karbi's are concentrated in the Karbi Anglong district and the foothills area of Nagoan and Kamrup districts while the Demasa Kacharis are mainly found in the North Cachar district. Besides, Hajong, Hmar, Rengma, Naga, Kuki, garo are also dominant groups inhabited in the hills of Assam. Rest of the tribal groups belongs to the plain tribes.

Among STs, Boro represents nearly half of the total ST population of the state (40.9 per cent). Miri (17.8 per cent), Mikir (10.7 per cent), Rabha (8.4 per cent), Kachari (i.e. Sonowal Kachari) (7.1 per cent), and Lalung (5.2 per cent) are the other major STs each having 5 per cent or above of total STs. Along with Boro they constitute 90 per cent ST population of the state. Besides them, Dimasa constitutes 3.4 per cent and Deori 1.2 per cent of the total ST population of the state. The rest of the Scheduled Tribes are very small in their population size

Population of Major STs, 2001 Census

\begin{tabular}{|l|l|l|l|}
\hline SL. & $\begin{array}{l}\text { Name of the } \\
\text { Scheduled Tribe }\end{array}$ & Total population & $\begin{array}{l}\text { Proportion } \\
\text { to the total ST population }\end{array}$ \\
\hline 1 & All Scheduled Tribes & $3,308,570$ & $100 \%$ \\
\hline 2 & Boro & $1,352,771$ & 40.9 \\
\hline 3 & Miri & 587,310 & 17.8 \\
\hline 4 & Mikir & 353,513 & 10.7 \\
\hline 5 & Rabha & 277,517 & 8.4 \\
\hline 6 & Kachari & 235,881 & 7.1 \\
\hline 7 & Lalung & 170,622 & 5.2 \\
\hline 8 & Dimasa & 110,976 & 3.4 \\
\hline 9 & Deori & 41,161 & 1.2 \\
\hline
\end{tabular}

The ST population in Assam is predominantly rural with 95.3 per cent rural and only 4.7 per cent urban population. Of the eight major STs, Dimasa have recorded the highest 10.4 per cent urban population, followed by Mikir ( 8.3 per cent). On the other hand Miri have recorded the lowest 1.8 per cent urban population. North Cachar Hills and Karbi Anglong the two autonomous hill districts of Assam are predominantly tribal housing two important STs of Assam - the Dimasa and Mikir (now recognized as Karbi). As per 2001 Census, the North Cachar Hills has got the highest 68.3 per cent ST population, followed by Karbi Anglong (55.7 per cent). In absolute number Karbi Anglong is on top sharing 13.7 per cent of the total ST population of the state. Hailakandi, Karimganj, and Cachar districts have a negligible presence of ST population

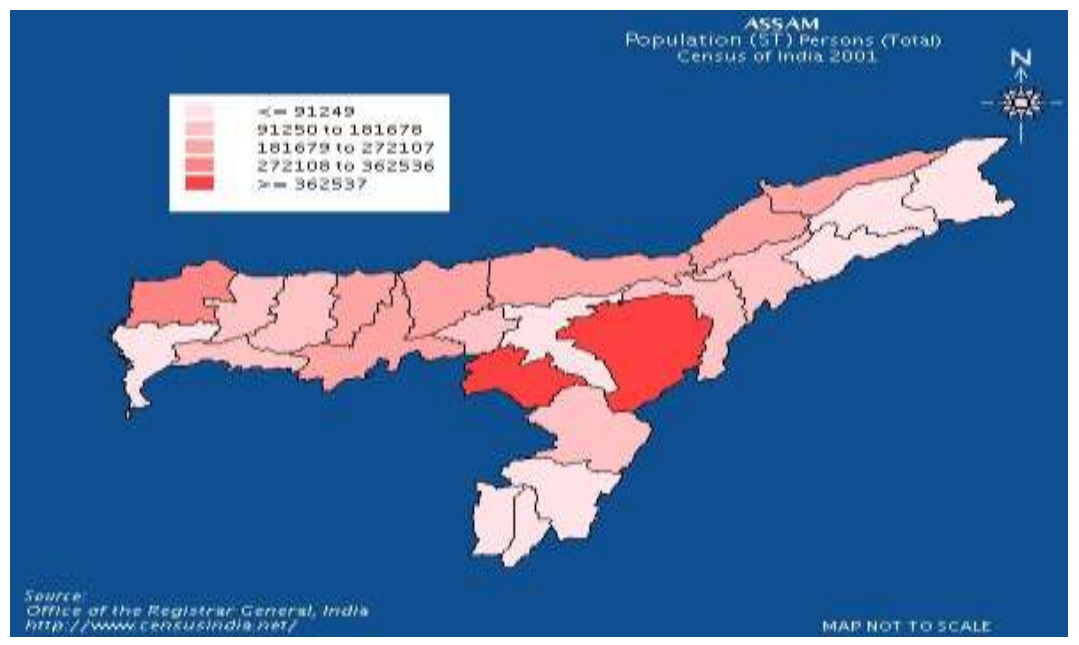


Spatial Distribution Of Tribal Population And Inter Tribal Differences In Population Growth: A

Among the Tribes of Assam the Boro Kachari are concentrated in the district of Kokrajhar, Kamrup, Nalbari, Darrang and Barpeta, whereas the Miri/Mishing belt are located in Sonitpur, Lakhimpur and Dhemaji district. Sonowal Kachari constitutes the third highest tribal group distributed mainly in the Dibrugarh and Golaghat districts. Rabha tribes stood in the forth position interms of population size mainly concentrated in the southern bank of the river Brahmaputra especially in the Goalpara and Kamrup. Deori community, a riverine tribal is the sixth largest in size found mainly in Lakhimpur, Dibrugarh, Jorhat and Sibsagar district. The next group is the Barman of Cachar found exclusively in the Cachar district. Tiwas are spread in the tribal belt of Nagoan and Morigaon district.

Another interesting aspect of tribal distribution of Population in Assam is that a large number of tribal Groups lives in Brahmaputra valley and only a small proportion likes in Barak Valley.

District wise Schedule Tribe population 2001

\begin{tabular}{|c|c|c|c|c|c|}
\hline $\begin{array}{l}\text { SL. } \\
\text { No }\end{array}$ & State/ District & $\begin{array}{c}\text { Total ST } \\
\text { Population }\end{array}$ & Percentage & Rural & Urban \\
\hline 1 & ASSAM & 26655528 & 12.41 & 13.59 & 4.48 \\
\hline 2 & North Cachar Hills & 188079 & 68.28 & 81.15 & 40.43 \\
\hline 3 & Karbi Anglong & 813311 & 55.69 & 57.83 & 38.96 \\
\hline 4 & Dhemaji & 571944 & 47.29 & 49.54 & 16.46 \\
\hline 5 & Kokrajhar & 905764 & 33.67 & 34.82 & 18.58 \\
\hline 6 & North Lakhimpur & 889010 & 23.49 & 24.95 & 5.05 \\
\hline 7 & Nalbari & 1148824 & 17.63 & 18.05 & 0.72 \\
\hline 8 & Darrang & 1504320 & 16.61 & 17.19 & 5.58 \\
\hline 9 & Goalpara & 822035 & 16.03 & 17.23 & 2.58 \\
\hline 10 & Marigoan & 776256 & 15.55 & 15.77 & 11.27 \\
\hline 11 & Jorhat & 999221 & 12.32 & 14.60 & 1.33 \\
\hline 12 & Bongaigoan & 904835 & 12.23 & 13.41 & 3.71 \\
\hline 13 & Sonitpur & 1681513 & 11.60 & 12.77 & 1.62 \\
\hline 14 & Kamrup & 2522324 & 9.93 & 13.50 & 3.58 \\
\hline 15 & Golaghat & 946279 & 9.93 & 10.56 & 3.11 \\
\hline 16 & Barpeta & 1647201 & 7.48 & 8.03 & 0.94 \\
\hline 17 & Dibrugarh & 1185072 & 7.45 & 8.24 & 4.16 \\
\hline 18 & Tinsukia & 1150062 & 5.85 & 6.97 & 1.20 \\
\hline 19 & Sibsagar & 1051736 & 3.95 & 4.21 & 1.43 \\
\hline 20 & Nagoan & 2314629 & 3.86 & 4.31 & 0.58 \\
\hline 21 & Dhubri & 1637344 & 1.99 & 2.20 & 0.38 \\
\hline 22 & Cachar & 1444921 & 1.29 & 1.46 & 0.25 \\
\hline 23 & Karimganj & 1007976 & 0.29 & 0.27 & 0.46 \\
\hline 24 & Hailakandi & 542872 & 0.15 & 0.16 & 0.10 \\
\hline
\end{tabular}

The spatial contention of tribal population in tribal belts and blocks in the plains area of Assam could be sub divided into the following:

Spatial Distribution of Tribal in The plains

\begin{tabular}{|l|l|l|l|}
\hline $\begin{array}{c}\text { Sl. } \\
\text { No }\end{array}$ & \multicolumn{1}{|c|}{ Name of the Belt/Block } & \multicolumn{1}{|c|}{ District } & \multicolumn{1}{|c|}{ Major Plain Tribes } \\
\hline $\mathbf{1}$ & Sidli Tribal Belt & Kokrajhar & Boro \\
\hline $\mathbf{2}$ & Bijni Tribal Block & Bongaigaon & Boro \\
\hline $\mathbf{3}$ & Rani Chaygaon Tribal Belt & Kamrup & Rabha \\
\hline $\mathbf{4}$ & Kherti-Sonapur Tribal Belt & Kamrup & Rabha, Lalung \\
\hline $\mathbf{5}$ & Tamulpur Tribal Belt & Nalbari & Boro \\
\hline $\mathbf{6}$ & Baska Tribal Belt & Nalbari & Boro \\
\hline $\mathbf{7}$ & Chapaguri Tribal Block & Barpeta & Boro \\
\hline $\mathbf{8}$ & Kariji Bijni Tribal Block & Barpeta & Boro \\
\hline $\mathbf{9}$ & Bajegaon Tribal Block & Barpeta & Boro \\
\hline $\mathbf{1 0}$ & Gabardhans Tribal Block & Barpeta & Boro \\
\hline $\mathbf{1 1}$ & Gohpur Tribal Block & Sonitpur & Miri/ Mishing \\
\hline $\mathbf{1 2}$ & Balipara Tribal Belt & Sonitpur & Boro \\
\hline
\end{tabular}


Spatial Distribution Of Tribal Population And Inter Tribal Differences In Population Growth: A

\begin{tabular}{|c|c|c|c|}
\hline 13 & Teteli Bhanguri Tribal Block & Darrang & Boro \\
\hline 14 & Kacharipara Tribal Block & Darrang & Boro \\
\hline 15 & Dalgaon Tribal Block & Darrang & Boro \\
\hline 16 & Lalai Tribal Belt & Darrang & Boro \\
\hline 17 & Tezial Tribal Block & Darrang & Boro \\
\hline 18 & Bhuiankhat Tribal Block & Darrang & Boro \\
\hline 19 & North Lakhimpur Tribal Belt & North Lakhimpur & Miri/Mishing \\
\hline 20 & Murkongselek Jonai Tribal Belt & Dhemaji & Miri/Mishing \\
\hline 21 & Bihpurian Subansiri Tribal Block & North Lakhimpur & Miri, Deori \\
\hline 22 & Abor-Misimi Tirap Tribal Block & Tinsukia & Miri, Deori, Sonowal \\
\hline 23 & Boro Kachari Tribal Belt & Nagaon & Lalung \\
\hline 24 & Amgurichang Phulgurichang Tribal Block & Nagaon & Lalung \\
\hline 25 & Bordalang Lankabheta Tribal Block & Nagaon & Lalung \\
\hline 26 & Baguriguri Tribal Block & Nagaon & Lalung \\
\hline 27 & Barchoi Tribal Block & Nagaon & Lalung \\
\hline 28 & Borchila Tribal Block & Nagaon & Lalung \\
\hline 29 & Borpathar Tribal Block & Kamrup & Lalung \\
\hline 30 & Jamadari Tribal Block & Kamrup & Lalung \\
\hline 31 & Borongoni Pathat Tribal Block & Kamrup & Lalung \\
\hline 32 & Changana Tribal Block & Kamrup & Lalung \\
\hline 33 & Tetelia Tribal Block & Kamrup & Lalung \\
\hline 34 & Gobha Tribal Block & Kamrup & Lalung \\
\hline 35 & Rhulaguri Tribal Block & Kamrup & Lalung \\
\hline 36 & Bagariguri Tribal Block & Kamrup & Lalung \\
\hline 37 & Bhulukjari Tribal Block & Kamrup & Lalung \\
\hline
\end{tabular}

It is in the tribal areas of the country that the process of redistribution of population seems to be taking place at an alarming rate. The process perhaps began during the colonial period itself when the resource-rich tribal areas, particularly in mid- India were exposed to colonial exploitation. This resulted in organized movement of the non-tribal elements deep into the monolithic tribal areas changing not only the ethnic composition but also bringing about far reaching changes in their socio-economic order. The land-hungry peasants too made deep inroads into the fertile tracts in the tribal habitats, resulting in an unprecedented redistribution of tribal population. Evidences of redistribution of tribal population are spatially contained in the fragmented cores and peripheries of many tribal groups living in central India. The tribal groups who were in any case distributed in 'geographically negative areas' were further squeezed into more inhospitable tracts or had to move out to newly emerging towns to work there in the unorganized tertiary sector of the economy.

Such a process of redistribution was experienced in the North-Eastern region of India-a region supporting large concentration of scheduled tribes and a legion of ethnically differentiated tribes-though on a much smaller scale and much different in quality. The most significant aspect of spatial distribution of tribal population in this region is an almost exclusive concentration of the tribes in the hilly region and in some areas of Brahmaputra Valley. It is the latter, which has been subjected to redistribution of population more than the former. The Bodo community, which is widely distributed as a one of the very few 'plains tribe', has been experiencing a great redistribution of its population both in the past as well as in the present, if the data available in censuses is of any indication.

Since the starting of this century, following large scale influx of immigrants especially from undivided Bengal (now Bangladesh) and Nepal into Assam, a sense of fear psychosis of insecurity has developed among the indigenous people including tribals. Thus the tribal being alarmed at this has ethnically united to form a tribal league in assam as early as 1933. Recently most of the tribes of Assam have been demanding separate homelands for them like Bodoland, autonomous state for Karbi and Dimasa groups, autonomous district for Rabha Hasong. Miri/Mishing and Tiwas. In the light of the above discussion an attempts have been made hare to study the spatial distribution pattern of the different tribal groups, and the locational attributes contributing to their territorial isolation, socio-economic and political demand of the tribals and the prospect of a viable solution to their problems in the Brahmaputra Valley.

The total population of the Brahmaputra valley as per 1901 census was 2619077 persons and the tribal population in that year was 369252 persons, constituted 14.1 percent of the total population of the valley. The proportion of tribal population had decline to 10.67 percent by 1971 (census report) and the same was computed to 12.71 percent in 1991 . The fall of the proportion of the tribal population to the total population of the state during the period 1901-2001 may be attributed to the very high growth of the population of the state as a result 
of huge influx of migrants into the state from outside the region and also natural growth of all the indigenous groups of population including non tribal.

From the table above it is also observed that the tribal population in the state generally avoid strong urban influence and their spatial concentration have a direct correlation with the districts from the large town. Most of the tribal population seems to be allergic to urban influence and spatially they are found to be distributed in areas beyond the zone of urban influence. North Cachar Hills, Karbi Anglong and Dhemaji are the least urbanized district in the state with high concentration of tribal population.

Illegal migration from Bangladesh into Assam has been a major political, economic, social and security issue for Assamese society, so much so that it evoked the non-violent, highly visible, Assam Agitation (19791985) spearheaded by the All Assam Students Union (AASU). That agitation resulted in the Assam Accord of 1985 which stated that anybody settled in Assam from Bangladesh after March 25, 1971 is not a citizen, but an illegal migrant. This provision of the Accord has not been implemented and has therefore failed to change the nature of Bangladeshi immigration into Assam, now termed as a "silent invasion" with the majority of the infiltration taking place through the Dhubri district in lower Assam bordering West Bengal, the districts of Cachar and Karimganj in Assam bordering Bangladesh and the $443 \mathrm{~km}$ Bangladesh-Meghalaya border. Assam shares a highly porous 262 kilometre border with Bangladesh with portions of it left completely unchecked due to the difficult nature of the terrain.

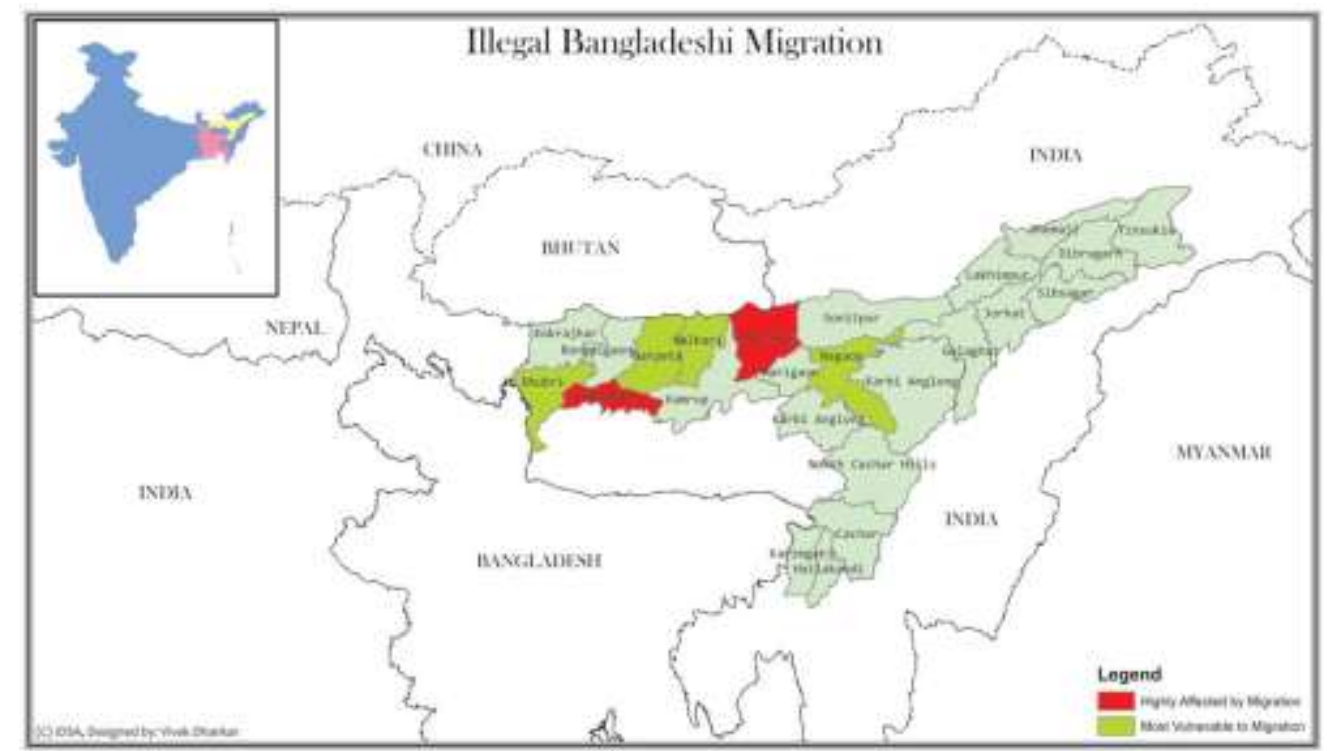

Though there is no documented data on the number of illegal migration, it is assumed that out of the 26 million people residing in Assam, around six million are illegal Bangladeshi migrants. Influential Assamese intellectuals like Dhiren Bezboruah, who is also the editor of The Sentinel warns that Assam could become a part of "Greater Bangladesh" with districts like Dhubri and Goalpara witnessing a change in their demographic profile by becoming migrant-dominated while other districts like Barpeta, Nalbari, Nagaon and Darrang are also heading in that direction.

Consequently, the illegal Bangladeshi migrants issue tends to dominate the political,economic, social, and security discourses in Assam with residents of the state expressing concern of being taken over demographically by this silent invasion. The lack of data on migration adds to a sense of being 'under siege' by outsiders as no one is sure as to the number of migrants visibly infiltrating all walks of life in Assam.

\section{Demographic Impact}

The Human Development Report 2009 (UNDP) on Migration is essentially pro-migration in approach and applies a human development approach to the study of migration ${ }^{1}$. When migrants integrate more and diffuse to a great degree within their adopted homeland, which in turn becomes more diverse, they have a better chance of being valued as enriching society and introducing complementary cultural traits ${ }^{2}$. Ground realities in India, however, indicate that this has not happened and the influx of migrants from Bangladesh and Nepal has raised several concerns.

\footnotetext{
${ }^{1}$ See, Human Development Report 2009 (UNDP, New York, 2009)

${ }^{2}$ Ibid., p.92.
} 
The sheer number of migrants from these two countries poses a demographic challenge. The S.K. Sinha Report on Illegal Migration into Assam 1998 clearly brings out perceptible changes in the demographic character of the state. It suggests that the influx of migrants threatens to reduce the Assamese people to a minority in their own state ${ }^{3}$. Sinha, in forwarding letter to the President, stated, "Large-scale illegal migration from East Pakistan/Bangladesh over several decades has been altering the demographic complexion of this State. It poses a grave threat both to the identity of the Assamese people and to our national security." ${ }^{, 4}$ Quoting Bangladesh census records, the report points out that there was a reduction of 39 lakh Hindus between 1971 and 1981 and another 36 lakh between 1981 and 1989; and contends that these 75 lakh Hindus have obviously come into India. Table 1 provides the relative decadal percentage growth of the population of Assam vis-à-vis India and what is now Bangladesh.

Table 1: Decadal Percentage Growth of Population

\begin{tabular}{|l|l|l|l|}
\hline Year & Assam & All India & $\begin{array}{l}\text { Area } \\
\text { Bangladesh }\end{array}$ \\
\hline $\mathbf{1 9 0 1 - 1 9 1 1}$ & 16.99 & 5.75 & 9.1 \\
\hline $\mathbf{1 9 1 1 - 1 9 2 1}$ & 20.48 & -0.31 & 5.4 \\
\hline $\mathbf{1 9 2 1 - 1 9 3 1}$ & 19.91 & 11.00 & 7.06 \\
\hline $\mathbf{1 9 3 1 - 1 9 4 1}$ & 20.40 & 14.22 & 17.6 \\
\hline $\mathbf{1 9 4 1 - 1 9 5 1}$ & 34.98 & 21.51 & 0.1 \\
\hline $\mathbf{1 9 5 1 - 1 9 6 1}$ & 34.95 & 24.80 & 29.83 \\
\hline $\mathbf{1 9 7 1 - 1 9 8 1}$ & 23.8 & 24.66 & 31.83 \\
\hline $\mathbf{1 9 8 1 - 1 9 9 1}$ & 23.8 & 23.85 & 22.00 \\
\hline $\mathbf{1 9 9 1 - 2 0 0 1}$ & 18.85 & 21.32 & -- \\
\hline
\end{tabular}

(Source: The S.K. Sinha Report on Illegal Migration into Assam, 1998)

The decadal population growth rate in Assam from 1951-1971 was higher as compared to the overall population growth rate in India and Bangladesh due to large-scale migration from Bangladesh. A look at community-wise population growth rates presents an even more revealing picture.

Table 2: Hindu and Muslim Population Growth Rates

\begin{tabular}{|l|l|l|l|l|}
\multirow{2}{*}{ Year } & Assam & Muslims & Hindu & Muslims \\
\cline { 2 - 5 } & Hindu & 38.35 & 20.29 & 25.61 \\
\hline $\mathbf{1 9 5 1 - 1 9 6 1}$ & 33.71 & 30.99 & 23.72 & 30.85 \\
\hline $\mathbf{1 9 6 1 - 1 9 7 1}$ & 37.17 & 77.42 & 48.38 & 55.04 \\
\hline $\mathbf{1 9 7 1 - 1 9 8 1}$ & 41.89 & &
\end{tabular}

Note: There was no census in Assam in 1981 because of the Assam agitation

(Source: The S.K. Sinha Report on Illegal Migration into Assam, 1998)

Table 2 clearly shows the quantum jump in the Muslim population of Assam because the illegal migrants coming into India after 1971 have been almost exclusively Muslims. ${ }^{5}$

In another study by the Institute of Defence Studies and Analysis (IDSA), Amarjeet Singh says that about 1.2 million Bangladeshis who entered India with valid travel documents have not returned home and that India managed to push back only 15,000 of them in 2005, 12,000 in 2006 and 11,500 in 2007. ${ }^{6}$ Some districts of Assam, such as Dhubri, Barpeta, Goalpara, Hailakandi and Karimganj, and several of West Bengal, such as Murshidabad, South and North 24 Parganas, Nadia, West Dinajpur, Jalpaiguri and Siliguri in Darjeeling, have a large Bangladeshi immigrant population.

\footnotetext{
${ }^{3}$ S.K. Sinha Report on Illegal Migration into Assam, submitted to the President of India, 1998

${ }^{4}$ S.K. Sinha Report, op.cit.

${ }^{5}$ Ibid.

${ }^{6}$ M. Amarjeet Singh, "Problems and Prospects of Illegal Migration in India," Asia 2030: The Unfolding Future (unpublished IDSA study, year not stated)
} 


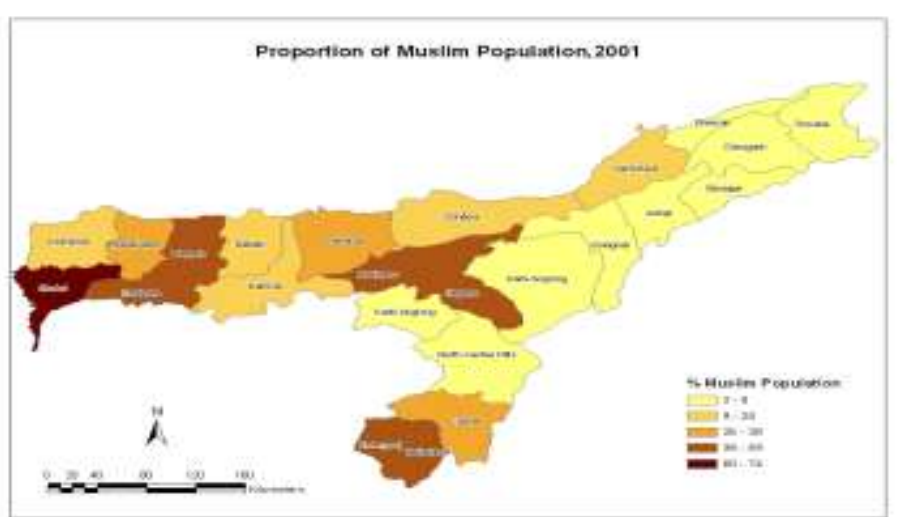

District wise Muslim Population in Assam

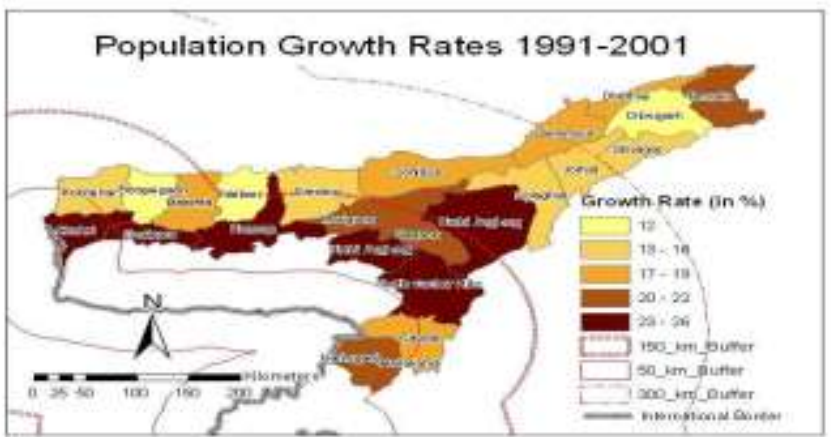

Assam's Population Growth Rates vis-à-vis the International Border

\section{Reference}

[1] Acharya, S.K. 1990. 'Ethnic Processes in North-Eastern India', in D. Pakem (ed.),Nationality, Ethnicity and Cultural Identity in North-East India, pp. 69-108. New Delhi: Omsons Publications.

[2] Baishya, P. 1991. 'Rural Industrialisation for Poverty Eradication in Assam', in R.K.Samanta (ed.), Rural Development in NorthEast India: Perspectives, Issues and Experiences, pp. 42-55. New Delhi: Uppal Publishing House.

[3] Banerjee, R. (1997). A critique of the Madhya Pradesh resettlement act. In W. Fernandes \& V. Paranjpye (Eds.). Rehabilitation policy and law in India: A right to livelihood. (p. 192-200). New Delhi: ISI \& Pune: Econet.

[4] Bandhopadhyay, Jayanta (1986) 'The Economics of Large Dams in India' in E. Goldsmith and N. Hildyard (eds.), Vol. 2.

[5] Basu, Malika (1996) 'Basic Needs Approach in Displacement Situations'. Mainstream, July-August.

[6] Baxi U. (1989). Notes on constitutional and legal aspects of rehabilitation and displacement. In W. Fernandes \& E. G. Thukral, (Eds.). Development, displacement and rehabilitation. (p. 164-170). New Delhi: Indian Social Institute.

[7] Bhanot, R \& Singh, M. (1992). The oustees of Pong dam: Their search for a home. In E.

[8] G. Thukral (Ed.). Big dams, displacement people: Rivers of sorrow, rivers of change.(p. 101-142). New Delhi: Sage.

[9] Das Gupta, M. 1991. The Impact of Land Reforms on North East India. New Delhi: Omsons.

[10] Fernandes, W. (1999). An introduction. In W. Fernandes (Ed.). The land acquisition (amendment) bill 1998. For liberalization or for the poor. New Delhi: ISI.

[11] Fernandes, W. \& Paranjpye, V. (Eds.). (1997). Rehabilitation policy and law in India: A right to livelihood. New Delhi: ISI \& Pune: Econet.

[12] Thukral, E.G. and M. Singh. 1995. 'Dams and the Dis placed in India', in H.M. Mathur

[13] (ed.), Development, Dis placement and Resettlement: Focus on Asian Experiences, pp. 93-121.New Delhi: Vikas Publishing House.

[14] Haksar, N. 1998. 'Law and the Self-management of Tribal Societies in North-east India,'in B. Singh (ed.), Antiquity to Modernity in Tribal India: Vol. II: Tribal Self-Management in North-east India, pp. 161-192. New Delhi: Inter-India Publications.

[15] Hussain, M. 2002. 'State Development and Population Displacement in North-East India', in C. Joshua Thomas (ed.), Dimensions of Displaced People in North-East India, pp. 282-98. New Delhi: Regency Publications.

[16] National Centre for Human Settlements and Environment (NCHSE). 1986. Rehabilitationof Displaced Persons due to Construction of Major Dams, Vol. 1. New Delhi: NationalCentre for Human Settlements and Environment.

[17] Nongbri, T. 1998. 'Gender Issues and Tribal Development', in B. Singh (ed.), Antiquityto Modernity in Tribal India: Volume II: Tribal Self-Management in North-East India,pp. 221-43. New Delhi: Inter-India Publications.

[18] Parasuraman, S. (1996). Development projects, displacement and outcomes for displaced.

[19] Two case studies. Economic and Political Weekly, xxxi (24), 1529-1532.

[20] Parasuraman. S. (1997). The anti-dam movement and rehabilitation policy. In J. Dreze, M. Samson, S. Singh (Eds.). The dam and the nation. Displacement and resettlement in the Narmada valley. (p. 26-65). Delhi: Oxford University Press.

[21] Parasuraman, S. (1999).The development dilemma. Displacement in India. London: Macmillan Press.

[22] Singh, Shekhar, Ashish Kothari and Kulan Amin (1992) 'Evaluating Major Irrigation Projects in India' in E. Ganguly Thukral (ed.) Big Dams: Displaced People. Sage Publications, New Delhi.

[23] Vyas, N. (1995). The social consequences of resettlement on tribals of Southern Rajasthan: A case study of Kadana project. In H. M. Mathur (Ed.). The resettlement of project affected people. (p. 57-78). Jaipur: HMC State Institute of Public Administration. 